\title{
Unexpected increases in rotifer resting egg abundances during the period of contamination of Lake Orta
}

\author{
Roberta PISCIA,${ }^{*}$ Simone TABOZZI,${ }^{1,2}$ Roberta BETTINETTI,${ }^{2}$ Liisa NEVALAINEN,${ }^{3}$ Marina M. MANCA ${ }^{1}$ \\ ${ }^{1}$ National Research Council, Institute of Ecosystem Study, Largo Tonolli 50, 28922 Verbania Pallanza, Italy; ${ }^{2}$ Department of Theoretical \\ and Applied Sciences, University of Insubria, Via Valleggio 11, 22100 Como, Italy; ${ }^{3}$ Department of Biological and Environmental \\ Science, University of Jyväskylä, P.O. Box 35, 40014 Jyväskylä, Finland \\ *Corresponding author: r.piscia@ise.cnr.it
}

\begin{abstract}
Despite their ecological importance and rapid response to environmental changes, rotifers are rarely included in palaeolimnological studies. Here, we describe changes in abundance (ABD) and morphotype (MTs) diversity of rotifer resting eggs in the sediments of deep subalpine Lake Orta, Italy, covering a period prior to (pre-) 1926, during long-term ammonia and metal pollution from a rayon factory, and subsequent recovery of water quality. Following the pollution and bacterial oxidation of the ammonia, Lake Orta became the largest and deepest acid lake in Europe. Recovery of water quality followed both a ban on the discharge of industrial wastes, and a liming intervention in 1989 and 1990. We sectioned a sediment core collected from the deepest part of the lake (ORTA 07/2A) to provide a high time resolution, given the ca. 3-4 y $\mathrm{cm}^{-1}$ of sediment accumulation. Rotifer resting egg abundance and morphotypes were examined from the sediments and compared to limnological variables indicating the pollution. Rotifer resting egg abundance significantly increased with lake contamination ( $r=0.609$ and -0.624 for copper and $p H$, respectively; $P<0.001 ; n=27)$. A lake-water copper concentration threshold of ca. $40 \mu \mathrm{g} \mathrm{L} \mathrm{L}^{-1}$ discriminated among pre-, during-, and post-pollution compositions of the rotifer morphotype assemblages. Diversity and morphotype richness increased during the recovery from copper pollution and with complete restoration from acidity, while abundance increased during pollution. The persistence of presumably viable Brachionus resting eggs and of hatched egg cases during the heavy pollution phase suggests that, unlike most other organisms, which were extirpated by the pollution of the lake, rotifers survived producing resting eggs, which secured future generations.
\end{abstract}

Key words: Paleo-ecotoxicology; Rotifera; diapause; Lake Orta; copper and ammonia pollution.

Received: July 2015. Accepted: October 2015.

\section{INTRODUCTION}

Lake sediments are an archive of past events, long-term trends and processes in both the water column and in the drainage basin. Examination of both biotic and abiotic markers allows qualitative and quantitative reconstructions of the past. Analyses of sediment cores, i.e. paleolimnological studies, have thus been used to reconstruct both impacts of long-term anthropogenic pollution and recovery from these impacts following remedial interventions (Battarbee 1999; Guilizzoni et al., 2001). Paleolimnological studies can also complement neo-limnological long-term records, providing evidence for patterns, mechanisms and rates of lake ecosystem response to changes in water quality (Cattaneo et al., 1998; Manca et al., 2004; Guilizzoni et al., 2011; Davidson and Jeppesen 2013). For example, analyses of sedimentary profiles of fossil diatoms, techamoebians, chironomid larvae and Cladocera have been used to quantify impacts of heavy metal pollution and acidification of Lake Orta, Northern Italy (e.g. Manca and Comoli, 1995). These studies provided evidence that water quality restoration did not result in the re-establishment of the original, pre-pollution, plankton communities. Differences in size structure across trophic levels (e.g. diatoms, thecamoebians and cladocerans), and within single taxa (i.e. Achnanthidium minutissimum (Kutz.) Czar.) also suggested that stress conditions (sensu Odum, 1965) induced by chronic pollution were responsible for a transition towards small-sized organisms, rapidly- reproducing and fast growing cladocerans (Cattaneo et al., 1998).

Copepods and monogonont rotifers, two important components of plankton and benthic food webs, have not, to date, been investigated paleolimnologically in Lake Orta. While copepods do not preserve well in the sediments (Frey, 1964), resting eggs of monogonont rotifers do (Gilbert and Wurdak, 1978; Jeppesen et al., 1996; Merkt and Müller, 1999), and the great variety of morphotypes makes rotifers a promising group for reconstructing past changes in planktonic biodiversity.

Monogonont rotifers represent a large fraction of plankton diversity in lakes (Pace and Orcutt, 1981; Visconti et al., 2008), and they are commonly responsible for a springsummer zooplankton population maximum (Orcutt and Pace, 1984; van Dijk and van Zanten, 1995; Yoshida et al., 2001). In the present study, we quantified changes in richness, diversity and abundance of rotifer resting eggs 
(RREs) in a sediment core of Lake Orta, Italy. Lake Orta is known for an 80-year episode of copper and ammonia pollution coupled with lake acidification caused by bacterial oxidation of the added ammonia (Mosello et al., 1986), and for a successful chemical restoration (Calderoni and Tartari, 2001). Our purposes were to determine:

i) if there were changes in abundance, richness and diversity of RREs during lake pollution and subsequent restoration;

ii) if different assemblages could be identified during different phases of the lake's environmental history, which we could reconstruct from contemporary and paleolimnological data;

iii) if changes of environmental conditions resulted in identifiable assemblage shift;

iv) if water quality restoration has promoted re-establishment of the pre-pollution planktonic rotifer communities.

We hypothesized: i) the rotifer resting egg Morphotypes (MTs) should increase in abundance and decrease in diversity, as observed in previous studies of acidic, metal-contaminated lakes (Yan and Geiling, 1985: Piscia et al., 2012); ii) the chemical restoration would not result in a re-establishment of the pre-pollution rotifer assemblage, a temporal pattern noted for both phytoplankton and crustacean zooplankton in the lake (Piscia et al., 2009; Morabito et al., 2001).

\section{METHODS}

\section{Study site}

Located in the subalpine Region, Lake Orta is a large Italian lake (maximum depth $143 \mathrm{~m}$, volume $1.3 \mathrm{~km}^{3}$; Lat N 4548' 54" and Long E 8²3'42'”; Fig. 1). In 1926, when a factory (Bemberg) producing artificial silk (rayon) began discharging huge amounts of copper and ammonium sulphate into southern end of the lake, lake water copper concentrations increased sharply, reaching a maximum of $108 \mu \mathrm{g} \mathrm{L}^{-1}$ in 1958; (Calderoni and Tartari, 2001; Fig. 1). Within three years, phytoplankton and zooplankton communities were decimated, and two years later fish disappeared (Monti, 1930; Baldi, 1949). Copper discharge to the lake was reduced from $80 \mathrm{t} \mathrm{y}^{-1}$ to about $9 \mathrm{t} \mathrm{y}^{-1}$ (Calderoni et al., 1990) in 1958, when the high cost of copper triggered changes in production technology. Heavy metal pollution of the lake, however, persisted as the wastewaters of newly established electro-galvanic factories were enriched in $\mathrm{Zn}, \mathrm{Ni}$ and $\mathrm{Cr}$, in addition to $\mathrm{Cu}$ (Bonacina et al., 1973; Calamari and Marchetti, 1975). Discharge of ammonia promoted bacteria nitrification, resulting in a decrease in water $\mathrm{pH}$, from neutrality $(\mathrm{pH} 7.2$ at winter overturn in 1926) to a minimum of $\mathrm{pH} 3.89$ (in 1985, at winter overturn). Because the whole lake basin was acidic, heavy metal ions persisted in the water col- umn, even after wastewater treatment was improved, in the early eighties (Bonacina, 2001). Estimates of unassisted recovery rates of water quality were lengthy (1520 years; Vollenweider, 1975). This led to a 1989-1990 liming intervention, which accelerated the $\mathrm{pH}$ rise to the desired threshold of 6 , a level deemed necessary to maintain low ammonium and heavy metal concentrations (Calderoni and Tartari, 2001). Neutralization of the whole water mass was achieved in 1991 and the concentrations of toxic metals have progressively declined. In 1999, the concentration of copper was close to zero in the whole water mass (Calderoni and Tartari, 2001). The lake has had neutral $\mathrm{pH}$ and low concentrations of toxic metal since that time (Rogora et al., 2016).

\section{Background information on Lake Orta's contemporary zooplankton}

Before pollution, Lake Orta was oligotrophic and well-known for its rich aquatic flora and fauna. Early studies (Pavesi, 1879; Monti, 1930) reported high abundances of several zooplankton taxa, including four Daphnia species (D. longispina, D. hyalina, D. galeata and D. pulex), two Cyclops (C. strenuus and C. tenuicornis), one Diaptomus (D. gracilis), and several rotifers. Other taxa, such as Leptodora hyalina, Diaphanosoma brachyurum and bosminids (B. longirostris and B. longicornis) were present in lower numbers.

Soon after the Bemberg factory began operation, the lake biota was decimated. Between 1939 and 1949 only some diatom and a few Rotifera taxa (namely Brachionus calyciflorus, Pallas, 1766) were able to persist in the openwaters (Baldi, 1949). Meanwhile, increased urbanization in the catchment led to symptoms of eutrophication, i.e. sporadic blooms of previously uncommon algal species (Oscillatoria rubescens De Candolle ex Gomont, 1892; Baldi, 1949) that had temporary competitive advantages over oligotrophic taxa under the deteriorated tin conditions of water quality.

Just prior to the lake liming intervention, small, fast growing rotifers increased in numbers and diversity, a time of improving water quality, i.e. between 1985 and 1990 zooplankton taxa number almost tripled (x 2.75), and $60 \%$ of the increase in richness was due to planktonic rotifers (Bonacina and Pasteris, 2001).

\section{Core chronology}

A $61.5 \mathrm{~cm}$ long sediment core (ORTA 07/2A) was collected in 2007 in Lake Orta's central basin with a gravity corer (inner diameter: $6.3 \mathrm{~cm}$ ) (coring depth $100 \mathrm{~m}$; Fig. 1). The core was stored in the dark at $4^{\circ} \mathrm{C}$, before being opened and longitudinally cut for visual inspection, lithological description and sub-sampling. The topmost $20 \mathrm{~cm}$ of the sediment core were cut every $1 \mathrm{~cm}$, while the rest of the core 
was sliced at every $5 \mathrm{~cm}$ intervals. A total of 28 samples were analyzed. Water and organic matter (OM) content were estimated on each sample from loss on ignition (LOI) at $60^{\circ} \mathrm{C}$ and $550^{\circ} \mathrm{C}$, respectively (Dean, 1974).

The core was dated from ${ }^{210} \mathrm{~Pb},{ }^{226} \mathrm{R}$ and ${ }^{137} \mathrm{Cs}$ activity in a direct gamma assay run at the Liverpool University Environmental Radioactivity Laboratory, using Ortec HPGe GWL series well-type coaxial low-background intrinsic germanium detectors (Appleby et al., 1986; Piscia et al., 2012).

Sediment accumulation rate ranged from a maximum of $0.27 \mathrm{~g} \mathrm{~cm}^{-2} \mathrm{y}^{-1}$ to a minimum of $0.029 \mathrm{~g} \mathrm{~cm}^{-2} \mathrm{y}^{-1}$ in the upper $13 \mathrm{~cm}$-section of core ORTA 07/2A. Accumulation rate was almost constant at $0.089 \pm 0.014 \mathrm{~g} \mathrm{~cm}^{-2} \mathrm{y}^{-1}$ in the deepest sections of the core $(13-61.5 \mathrm{~cm})$, in which sedimentation rate was around $0.29 \mathrm{~cm} \mathrm{y}^{-1}$ and unsupported ${ }^{210} \mathrm{~Pb}$ concentration declined with depth exponentially. The age at the core base was estimated as ca. $1800 \mathrm{AD}$, by extrapolating to the core bottom the oldest measured sedimentation rates. ${ }^{210} \mathrm{~Pb}$ dates calculated by CRS model placed 1986 at depth of $4.5 \mathrm{~cm}$ and 1963 at $12-13 \mathrm{~cm}$, in good agreement with results of ${ }^{137} \mathrm{Cs}$ record.

\section{Rotifer Resting Eggs}

A sugar flotation technique to extract Rotifer Resting Eggs (RREs) (Onbé, 1978, modified by e.g., Garcia

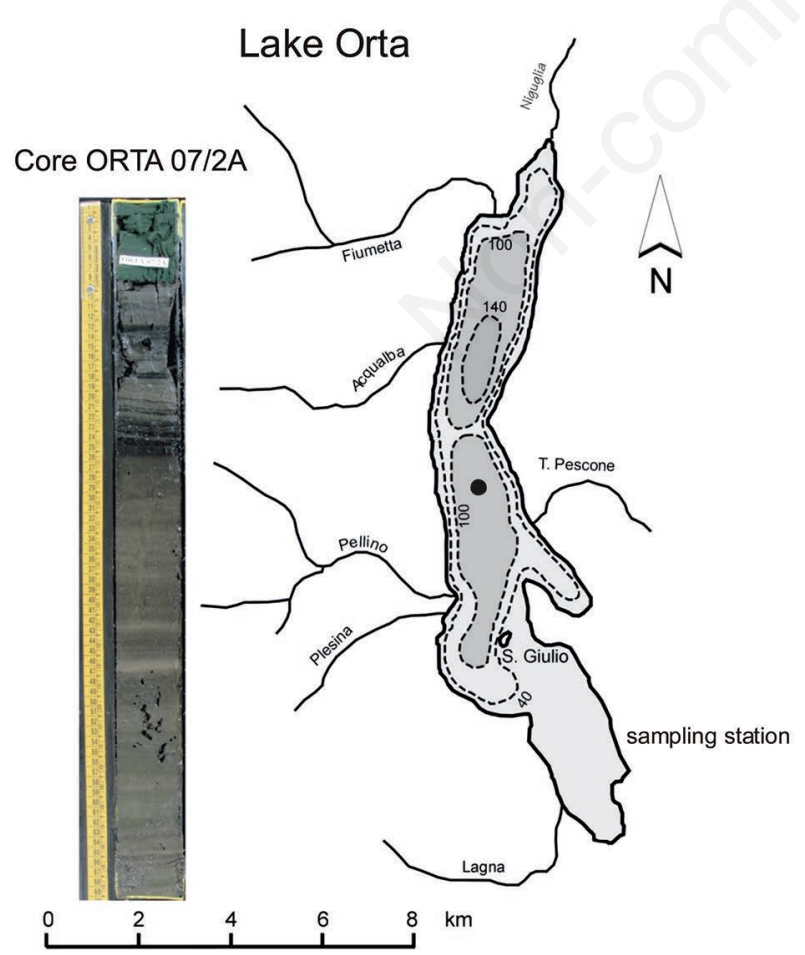

Fig. 1. Map of Lake Orta with the sampling station $(\bullet)$ of ORTA 07/2A sediment core (shown in picture).
Roger, 1995 for rotifers) from entire, pre-weighted sediment sections (ca. 8-20 g wet weight) was used. Success of extraction was checked by inspecting the sedimented fraction verifying that it always contained $<1 \%$ of the total count. The floated fraction, i.e., the samples, were counted in their entirety under a compound microscope (Zeiss Standard) connected to a computer program for image analysis (Image Pro Express, v. 5.1). Depending on the resting eggs' sizes, 63-400x magnification was used for counts. We identified MTs with progressive numbers as in Piscia et al. (2012), based on shape, size and surface sculpturing. Attribution to taxa was based on previous studies (Sudzuki, 1964; Koste, 1978; Piscia et al., 2012; Karina Jensen, NERI, DK, unpublished material).

We scored full and empty cases of Brachionus (Fig. 2), the latter being indicative of hatching, and thus the emergence of colonists that might establish active populations in the water column. Data on abundance were expressed as accumulation rates (eggs $\mathrm{m}^{-2} \mathrm{y}^{-1}$ ) and were based on complete counts of the whole sample. We estimated MTs richness ( $R s=$ number of MTs), Shannon-Weaver's $H$ diversity (Shannon and Wiener, 1963) and Pielou's evenness (e; Pielou, 1966), following these equations:

$H=\sum_{i=1}^{n} p_{i} \ln p_{i}$
$e=\frac{H}{\log _{2} n}$

where $p_{i}$ is the proportion of individuals of the $i^{\text {th }}$ MT and $n$ is the total number of MTS.

Between-sample differences in rotifer resting egg abundance (ABD), diversity $(H)$ and morphotype composition were analyzed by the non-parametric Kruskal-Wallis test; Spearman's rank correlation coefficient $\mathrm{R}$ was used to test the statistical significance between water $\mathrm{pH}$ and copper concentration, as well as sediment associated variables, such as OM content. We used Statistica v. 6 to perform statistical analysis.

To track changes in rotifer community composition in the sediment core we first applied detrended correspondence analysis (DCA) to determine the lengths of the compositional gradients. When the gradient lengths were longer than 2.5 standard deviation (SD) units, canonical correspondence analysis (CCA) was applied to MTs (relative abundance of morphotypes in each sediment section), and hydrochemistry data $\left(\mathrm{Cu}, \mathrm{pH}, \mathrm{Ca}, \mathrm{N}-\mathrm{NH}_{4}^{+}\right)$from the samples that covered the period of lake monitoring (22 samples, down to a core depth $25.5 \mathrm{~cm}$, ca. $1925 \mathrm{AD}$ ). Monitoring data, kindly provided by Calderoni (unpublished), were generated from samples of the water column at the deepest position (Qualba, $143 \mathrm{~m}$ depth) during winter mixing. 
Heavy metal concentrations were measured by Atomic Absorption Spectrophotometry (AAS) (GAAS Perkin Elmer). CCA was used to identify those components of the variation in MTs assemblages that could be explained by their correlation with environmental variables, and forward selection of environmental variables was performed. The significance of each environmental variable was tested with a Monte Carlo permutation test (999 unrestricted permutations) and the significance was set to $\mathrm{P} \leq 0.05$. MTs data were square root-transformed and rare species were downweighted. Analyses were performed with CANOCO v. 4.52 (ter Braak and Šmilauer, 2002).

\section{RESULTS}

The DCA ordination (Fig. 3a) was similar to the full CCA ordination with all environmental variables included (Fig. 4). In the DCA ordination of the samples and MTs (Fig.3a; gradient lengths are reported in Tab. 1) pre-pollution samples (until 1925 AD) and MT12, MT13, and MT15 had high DCA axis 1 scores whereas the recovery phase samples (1986-2005 AD) and the majority of MTs had low DCA axis 1 scores. MT6 (Brachionus calyciflorus; Piscia et al., 2012) and the pollution period samples (1938-1980 AD) had intermediate scores along the first axis (Fig. 3a).

A threshold was evident in the plot of DCA axis 1 sample scores in relation to lake copper concentrations. A $\mathrm{Cu}$ concentration of $\sim 40 \mu \mathrm{g} \mathrm{L}^{-1}$ separated the pollution period samples with intermediate scores from the pre- and post-pollution samples (Fig. 3b).

The CCA analysis (Fig. 4) clearly distinguished different time periods of the history of the lake. The samples
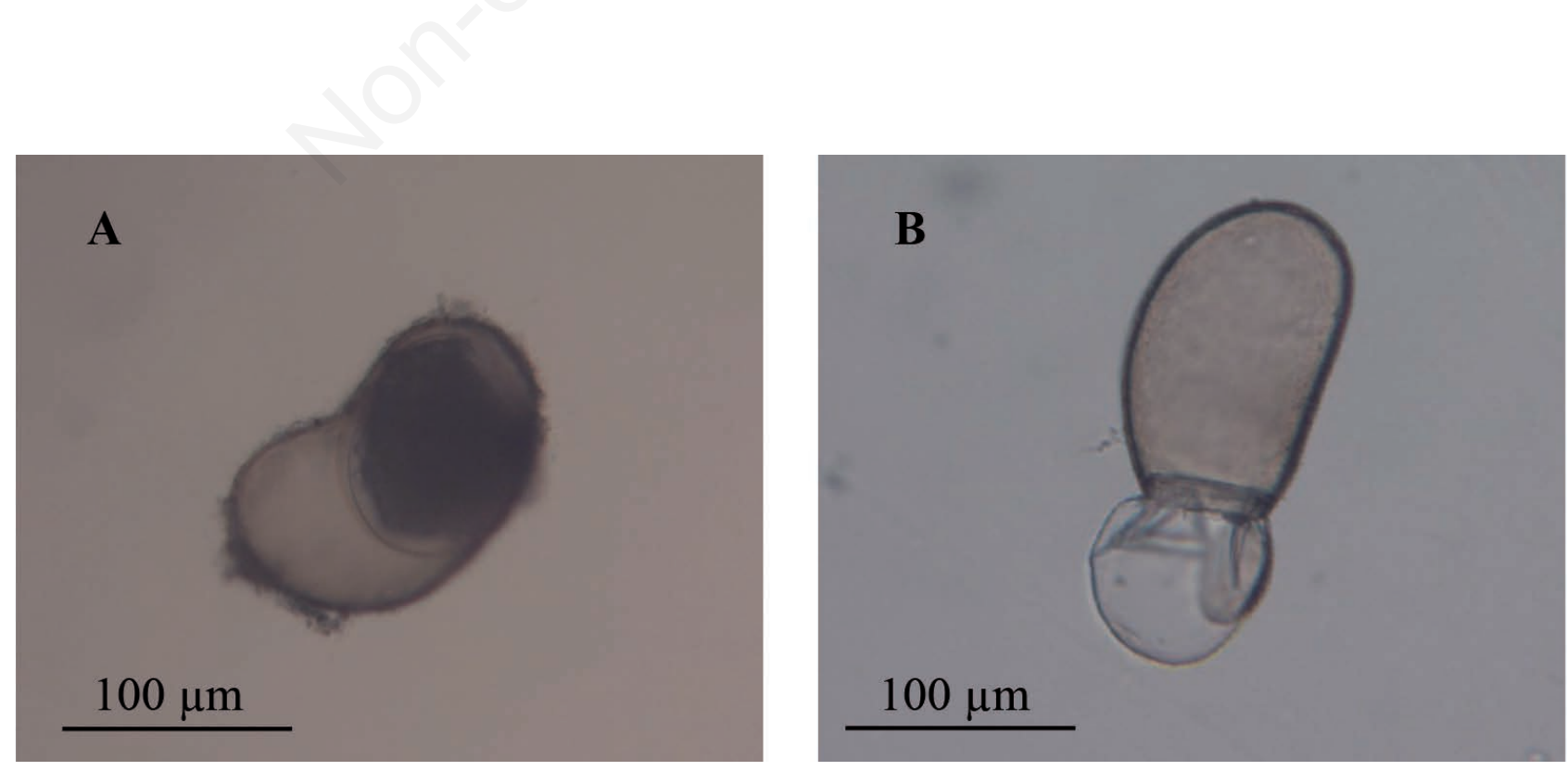

from the pollution and recovery time periods were on the opposite sides of the ordination, along $\mathrm{Ca}$ and $\mathrm{Cu}$ gradients. The largest number of MTs were associated with the recovery time period. The plot highlighted one additional separation between samples of the pollution period. The distribution of the latter was along the CCA axis 2 corresponding to $\mathrm{pH}$ and nitrogen $\left(\mathrm{N} / \mathrm{NH}_{4}\right.$ and $\left.\mathrm{N} / \mathrm{NO}_{3}\right)$ gradients. The full CCA model including all the 22 samples and five environmental variables resulted in eigenvalues of 0.536 and 0.249 for CCA axis 1 and 2, respectively. The species-environment correlations were high at 0.975 for axis 1 and 0.928 for axis 2 and the axes explained $48.6 \%$ and 33.2 of the cumulative variance. The analysis identified $\mathrm{Ca}$ and $\mathrm{N} / \mathrm{NO}_{3}$ as significant, together explaining $74 \%$ of the variance, whereas the other environmental variables did not make significant contributions. The eigenvalues for the CCA axis 1 and 2 were 0.522 and 0.219 , respectively.

Our first hypothesis was supported, i.e. the accumulation rate of rotifers resting eggs increased in sediments accumulated during the pollution period (Fig. 5). The increase was substantial. The abundance of resting eggs increased by ca. one order of magnitude in sections representing the beginning of the pollution, when the inlake copper concentration surpassed the threshold of about $40 \mu \mathrm{g} \mathrm{L}^{-1}$. We observed a second increase of one order of magnitude in the sediment sections between 17 and $14 \mathrm{~cm}$. The latter represented the years in which the concentration of copper in the water column reached its maximum $\left(\mathrm{Cu}=108 \mu \mathrm{g} \mathrm{L}^{-1}\right)$. In the upper part of the core (from $14 \mathrm{~cm}$ to the surface), the accumulation rate of resting eggs was quite stable, i.e. their abundance did not decreased with the recovery of the lake.

Fig. 2. Resting eggs of MT6 (Brachionus) full (A) and empty (B).

Fig. 2. Resting eggs of MT6 (Brachionus) full (A) and empty (B). 
We found changes in diversity $(H)$, MT richness $(R s)$ and evenness $(e)$ in the different sediment core zones. $R s$ reached its maximum (20) in recovery sediment sections where $H$ was also high (2). The statistical analysis confirmed these observations. In zones between 5 and $18 \mathrm{~cm}$, $R s, H$ and $e$ were low. The maximum $H$ (2.6) and $e$ (1) were attained in sections $18-25 \mathrm{~cm}$, i.e. with $R s=7$. In prepollution sections, a very low $R s(0-2)$ at similar abundances resulted in $e$ value (eq. 1) very close to that those of the beginning of the pollution $(18-25 \mathrm{~cm})$.

Abundance, $H$ diversity and $R s$ changed between pre, during- and post-copper pollution periods. The KruskalWallis test (Tab. 2) identified differences in MT richness $(R s)$ among the pollution and recovery phases, while the abundances of eggs differed only in the pre-pollution period. $H$ differed significantly only between pre- and postpollution phases.

Assemblages of resting eggs of rotifer MT changed over time (Fig. 4) and, as we hypothesised, the post-pollution composition was different from the pre-pollution one. MT6 and MT4 characterized pre-pollution sediment sections. MT4 was also dominant in the upper part of the core $(5-0 \mathrm{~cm})$, in which the accumulation of MT3, MT16 and MT17 stabilized. MT3 was a dominant feature of the assemblage in the pollution period, and full and empty egg cases of MT6, were also abundant at that time.

RREs' abundance (Tab. 3) was positively correlated to both sediment (Vignati et al., 2016; $\mathrm{R}=0.729, \mathrm{n}=27$,
$\mathrm{P}<0.001)$ and in-lake copper concentrations $(\mathrm{R}=0.609$, $\mathrm{n}=27, \mathrm{P}<0.001)$. We found also a negative $(\mathrm{P}<0.001)$ correlation with water $\mathrm{pH}$.

\section{DISCUSSION}

Paleolimnological studies have only rarely considered RREs as proxy records (Jeppesen et al., 1996; Merkt and Müller, 1999; Piscia et al., 2012) to infer environmental conditions of the past. The purposes of the present study were to ascertain if the different phases of Lake Orta (prepollution, pollution and recovery) could have produced changes in abundance, diversity and MTs assemblages of RREs. We hypothesized an increase in abundance of the RREs and a decrease of their diversity during the pollution period, and that different MTs combinations might characterized the pre-pollution and recovery period. The observations were consistent with our hypotheses.

The CCA bi-plot has attributed every sample to a specific phase of the lake. The CCA analysis identified the sections of the core between 15 and $26 \mathrm{~cm}$ (ca. 1958-1920) as representative of the first phase of the pollution, during which in-lake copper concentration increased but $\mathrm{pH}$ remained neutral (Fig. 4). In those sections, we have found a consistent increase in RRE abundance, confirmed, by statistical analysis (Tab. 1) and a change in MTs assemblage. Some rotifer species (e.g. Synchaeta pectinata; Gilbert, 1995), can produce resting eggs, but usually they are the a)

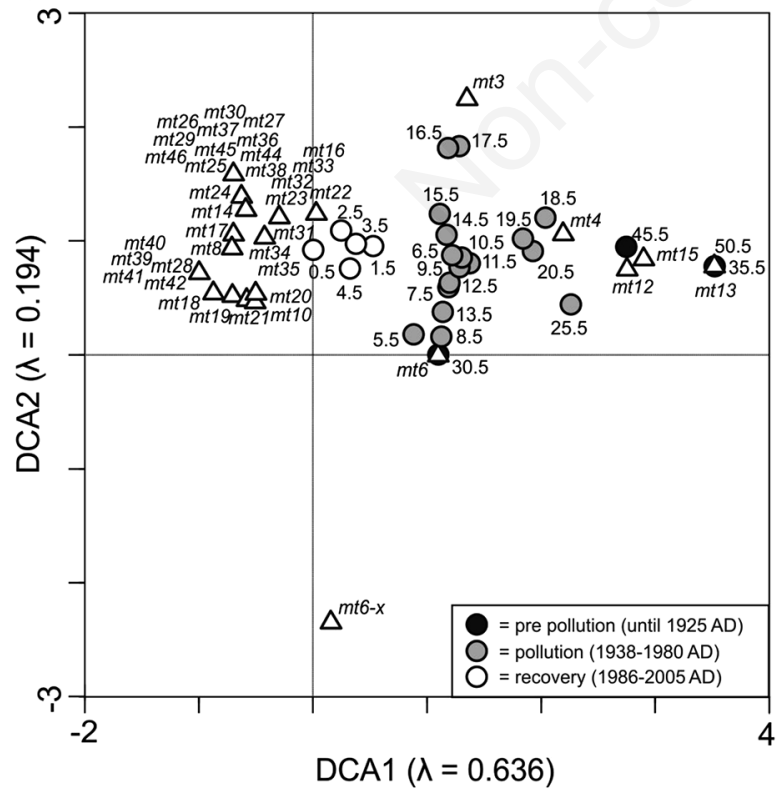

b)

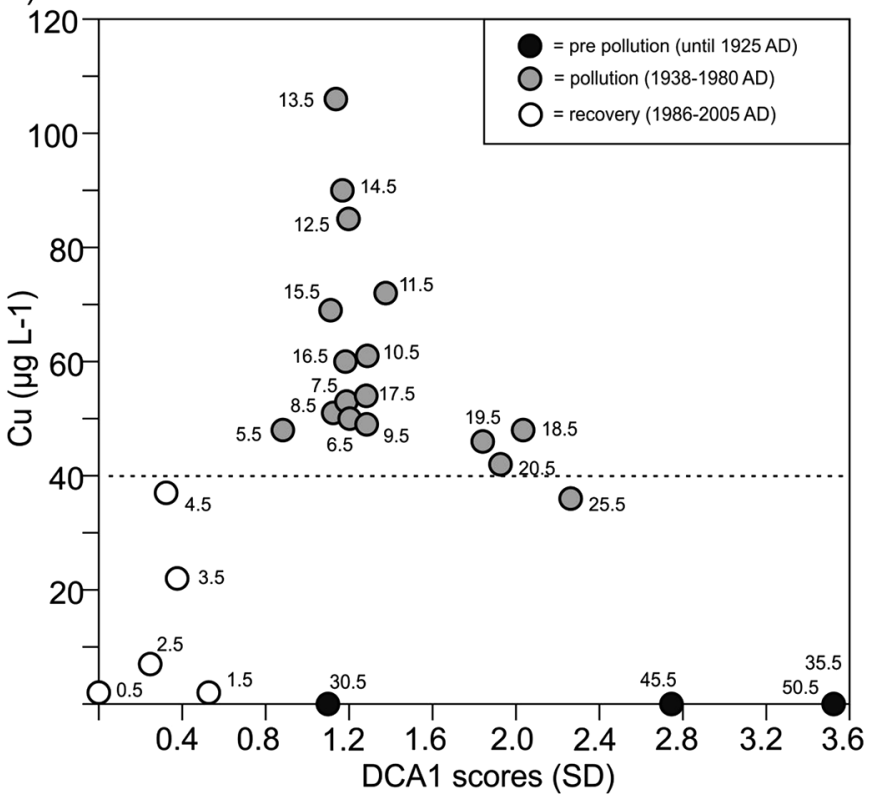

Fig. 3. a) Detrended Correspondence Analysis (DCA) ordination of rotifer resting eggs MTs (indicated by white triangles) and samples (dots) and b) DCA axis 1 sample scores plotted in relation with copper concentrations with a dashed line representing a Cu-threshold for non-polluted and polluted samples. 
result of a shift from parthenogenesis to sexual reproduction. Environmental cues, such as crowding and photoperiod, are factors promoting such shift (Gilbert, 1992, 2007). We cannot exclude the possibility that a pollutant might directly induce the production of resting stages, as a bethedging strategy to assure future generations, but this is currently only speculation. However, the increase of inlake copper concentration might indirectly benefit the production of RREs. A study conducted in six acidified and metal-polluted lakes in Canada (Yan and Geiling, 1985) demonstrated that the great abundance of planktonic rotifers was attributable to a reduction in densities of crustacean competitors, as consequence of the pollution. The differences in accumulation rates, also, might be a consequence of losses because of predation and/or taphonomic processes. However, the latter two could be not so important in Lake Orta, because much older and well preserved RREs (dating back to ca. 1400 AD), were found in a previously analyzed sediment core (Piscia et al., 2012).

We can reasonably infer the change in MTs assemblage, observed in sediment sections deposited during the pollution phase are a direct consequence of the increasing in-lake copper concentration. The ability to survive in presence of a toxicant varies greatly between species and it can be also be regulated by other environmental factors. Rotifers can tolerate remarkably high copper concentrations (of ca. around $100 \mu \mathrm{gL}^{-1}$ ) (Yan and Geiling, 1985; Peretz et al., 2001), fully comparable to those of Lake Orta during heavy pollution phase (1930-1980). In addition, production of RREs by planktonic and pelagic species may have been supplemented by benthic and littoral species, which might have colonized microhabitats with more favorable environmental conditions.

Sediment sections between 5 and $15 \mathrm{~cm}$ (ca. 19551959) of the core were representative of the second phase of pollution, a phase characterized by decreases in copper concentration, lined to reduced industrial discharges, in-

Tab. 1. Detrended Correspondence Analysis (DCA; Fig. 4) results.

\begin{tabular}{lcc} 
& Gradient lengths & SD $(\lambda)$ \\
DCA axis 1 & 3.523 & 0.636 \\
DCA axis 2 & 1.831 & 0.194 \\
\hline
\end{tabular}

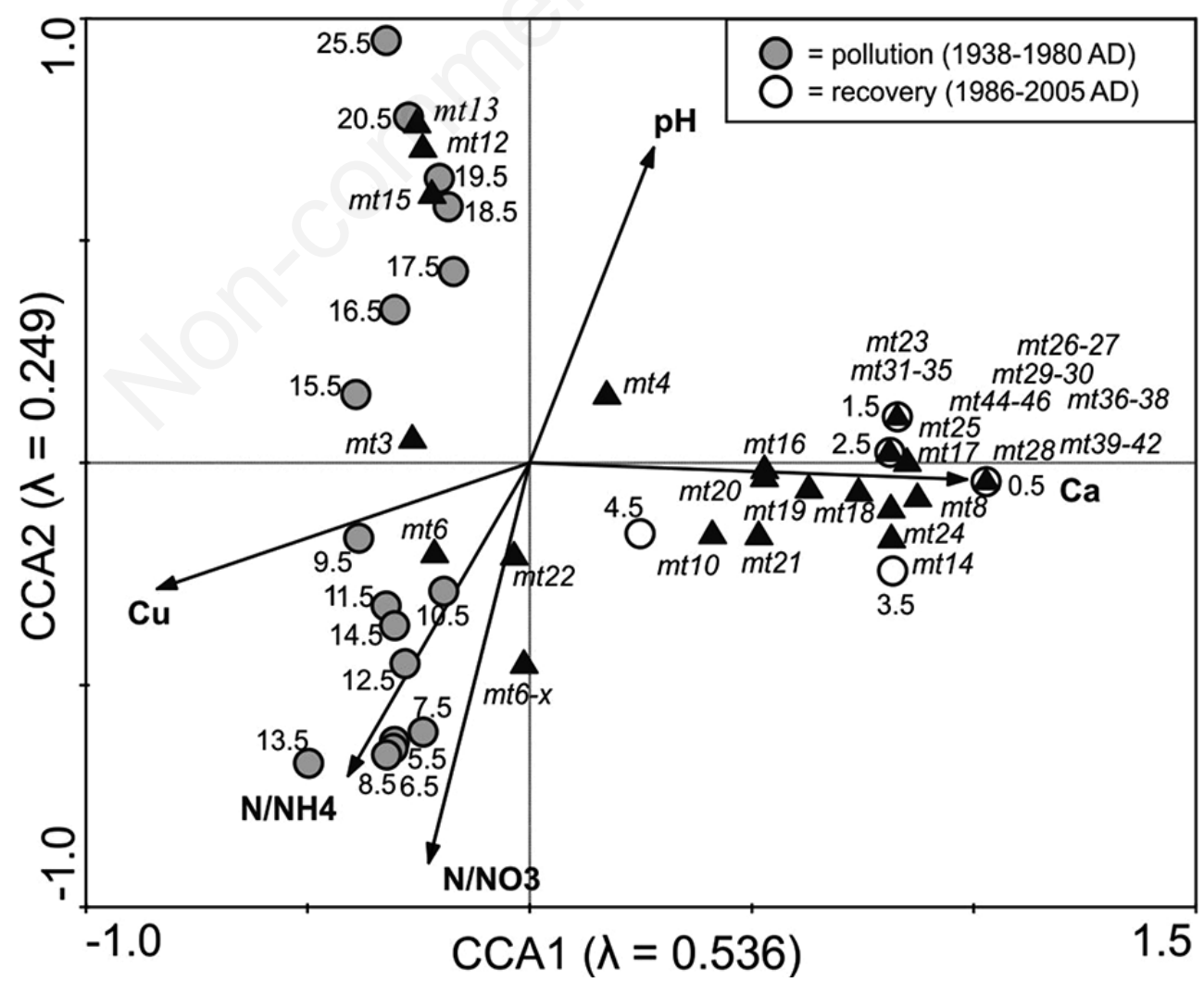

Fig. 4. Canonical correspondence analysis (CCA) ordination of the relationship between the measured environmental parameters (arrows) and samples (dots)/MTs (black triangles) 
creases in ammonia and acidification (Figs. 3 and 4). Increased lake acidification might have promoted production of resting eggs by more taxa and/or promoted

Tab. 2. Multiple statistical comparison [Kruskal-Wallis H test $(2, n=26)]$ of data on rotifer resting egg MTs in core ORTA 07/2A sections before, (0), during (1) and after (2) copper pollution, distinction among the three based on water-column copper concentrations (for further explanation see text).

\begin{tabular}{lcc} 
Variable & $\mathrm{R}$ & $\mathrm{P}$-level \\
$\mathrm{ABD}_{\text {eggs }}$ vs $\mathrm{pH}$ & -0.624 & $\mathrm{P}<0.001$ \\
$\mathrm{ABD}_{\text {eggs }}$ vs $[\mathrm{Cu}]_{\text {water }}$ & 0.609 & $\mathrm{P}<0.001$ \\
\hline $\mathrm{ABD}_{\text {eggs }}$ vs $[\mathrm{Cu}]_{\text {sediment }}$ & 0.729 & $\mathrm{P}<0.001$
\end{tabular}

production of different morphotypes by the same taxa (Gilbert, 1995). A low number of MTs (Rs) was associated with these sections, but the abundances were stable. In

Tab. 3. Statistical comparison (Spearman rank correlation coefficient $\mathrm{R}, \mathrm{n}=27$ ) of data on rotifer resting eggs in the sediment core ORTA 07/2A.

\begin{tabular}{lcccl} 
& $0 / 1$ & $0 / 2$ & $1 / 2$ & \multicolumn{1}{c}{$\mathrm{P}$} \\
$H$ & $\mathrm{~ns}$ & 0.009 & $\mathrm{~ns}$ & 0.0094 \\
$\mathrm{Rs}$ & 0.008 & 0.000 & 0.036 & 0.000 \\
\hline $\mathrm{ABD}_{\text {eggs }}$ & 0.001 & 0.002 & $\mathrm{~ns}$ & 0.0004 \\
\hline
\end{tabular}

ns, not significant.

\section{Core ORTA 07/2A}

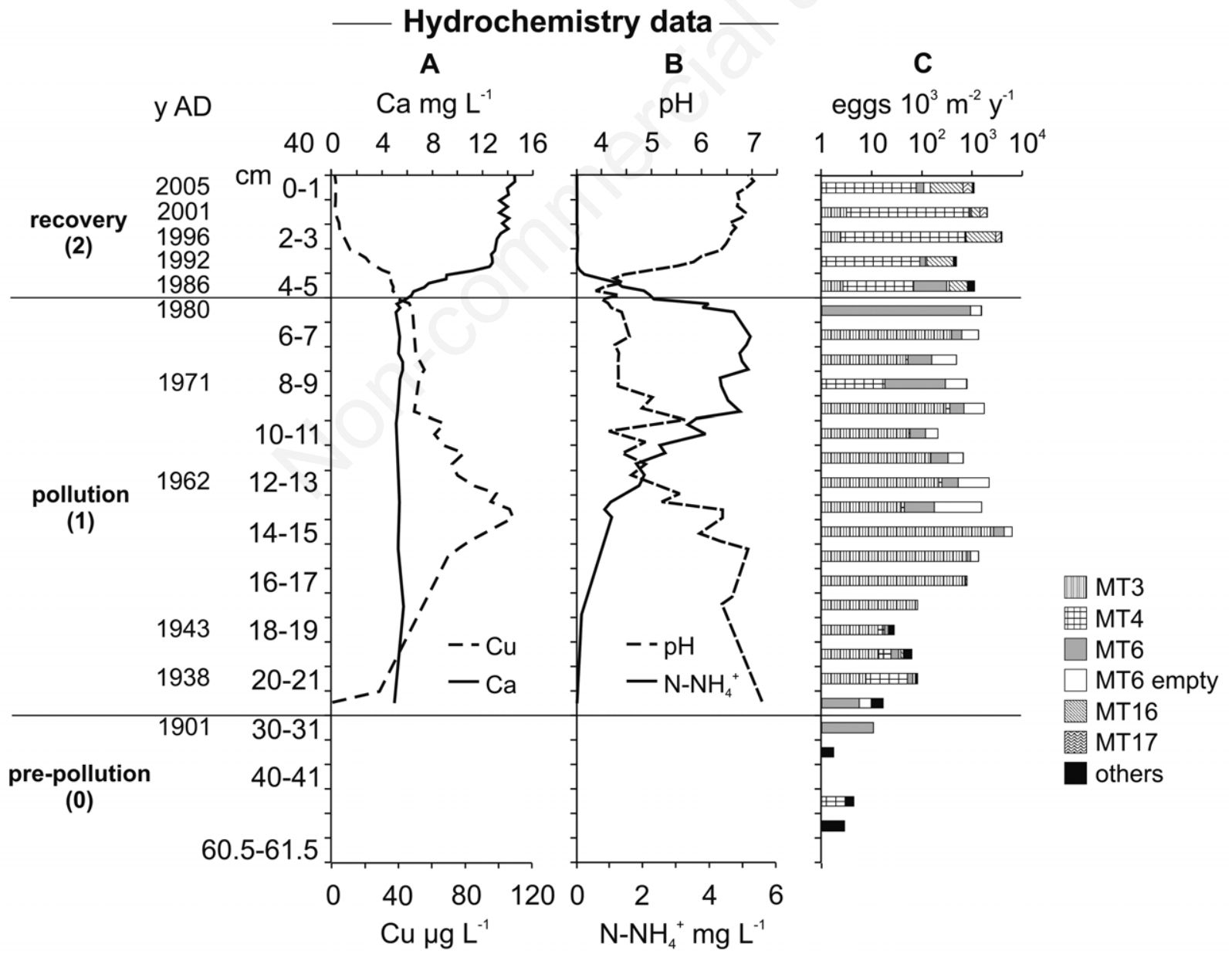

Fig. 5. Copper and calcium in-lake concentrations (A), pH and ammonia (B), measured in Lake Orta, in 1925-2007. C: accumulation rate of rotifer resting eggs MTs, on logarithmic scale. 
particular the presence of resting stages of Brachionus calyciflorus (MT6; Piscia et al., 2012), was in agreement with its high $\mathrm{Cu}$ tolerance. In a 48-h toxicity test on $\mathrm{Cu}$ to B. calyciflorus (Pallas), the NOEC of $\mathrm{Cu}$ increased 12fold, from 8.2 and $103 \mu \mathrm{gL}^{-1}$, depending on both DOC concentration and $\mathrm{pH}$ of the assay media (De Schamphelaere et al., 2006). The increase in empty egg cases of $B$. calyciflorus during heavy copper pollution might be indicative of an attempt to start active population.

The CCA analysis (Fig. 4) separated the core section representative of liming intervention $(4-5 \mathrm{~cm}$; ca. 19911986) from the sections representing recent early steps of recovery of the lake (0-4 cm; ca. 2007-1992), when ammonium decreased and $\mathrm{pH}$ increased ( $>4.5$ units) approaching neutrality, and ionic copper concentration was $\leq 40 \mu \mathrm{g} \mathrm{L}^{-1}$. Thus, the latter seems a threshold for discriminating differences in assemblages of pre-, during and post-pollution of the lake (Fig. 3).

RREs assemblage after lake's chemical recovery differed from that of before and during pollution. Diversity, expressed as Shannon-Weaver index $(H)$ changed only between pre-and post-pollution, while, diversity expressed as MTs richness (Rs) was statistically different in the all three-lake phase, with the lowest values during the pollution, as we have hypothesized.

\section{CONCLUSIONS}

Our analyses of the RRE profile in Lake Orta's sediment core encourages further studies on this often-neglected component of the zooplankton of deep lakes, but also on benthic and periphytic rotifers of shallow lakes, in which they are very important. Results were consistent with our expectations, in that we found increased abundance and decreased diversity of RREs during pollution periods, and also some differences in responses to the acidification vs. the copper pollution phases. Analyses of RREs enriches our understanding of community response to both pollution and recovery: unlike many cladocerans, diatoms and thecamoebians (Manca and Comoli, 1995; Cattaneo et al., 1998), rotifers persisted in the water column of the lake during the periods of severe pollution. According to contemporary data, their persistence might have been ephemeral; contemporary data however appear inadequate in this respect, given the fast reproductive rates of these organisms.

Given the persistence of Brachionus and the great viability of resting eggs RREs would appear to be useful for testing patterns and mechanisms of response to pollutants. Methods of resurrection ecology have been useful for daphniids (Piscia et al., 2015), and this approach could also be useful for future work on rotifers. Further research is needed, however, to address genetic diversity of these important components of the lake biota and to allow for a comparison between sediment-based and water columnbased diversity estimates.

\section{ACKNOWLEDGMENTS}

We are very grateful to Piero Guilizzoni for supporting us during all phases of the study, from planning and sediment core collection to critical discussion of results, and provision of contacts and financial support for sediment core chronology (by P. Appleby, UK). L. Nevalainen was supported by a personal grant from the Kone Foundation. We thank Norman Yan for comments on manuscripts drafts.

\section{REFERENCES}

Appleby PG, 2001. Chronostratigraphic techniques in recent sediments, p. 171-223. In: W.M. Last and J.P. Smol (eds.), Tracking environmental change using lake sediments. 1 . Basin analysis, coring, and chronological techniques. Kluwer Academic

Appleby PG, Nolan PJ, Gifford DW, Godfrey MJ, Oldfield F, Anderson NJ, Battarbee RW, 1986. ${ }^{210} \mathrm{~Pb}$ dating by low background gamma counting. Hydrobiologia 141:21-27.

Appleby PG, Oldfield F, 1978. The calculation of lead-210 dates assuming a constant rate of supply of unsupported ${ }^{210} \mathrm{~Pb}$ to the sediments. Catena 5:1-8.

Appleby PG, Richardson N, Nolan PJ, 1992. Self-absorption corrections for well-type germanium detectors. Nucl. Inst. Methods B 71:228-223.

Baldi E, 1949. [Il Lago d'Orta, suo declino biologico e condizioni attuali].[Article in Italian]. Mem. Ist. ital. Idrobiol. 5:145-188.

Battarbee RW, 1999. The importance of palaeolimnology to lake restoration. Hydrobiologia 395/396: 149-159.

Bonacina C, 2001. Lake Orta: the undermining of an ecosystem. J. Limnol. 60:49-57.

Bonacina C, Bonomi G, Ruggiu D, 1973. Reduction of the industrial pollution of Lake Orta (N. Italy): an attempt to evaluate its consequences. Mem. Ist. Ital. Idrobiol. 30:149-168.

Bonacina C, Pasteris A, 2001. Zooplankton of Lake Orta after liming: an eleven years study. J. Limnol. 60:49-57.

Calamari D, Marchetti R, 1975. Predicted and observed acute toxicity of copper and ammonia to rainbow trout (Salmo gairdnerii Rich.). Prog. Wat. Tech. 7:569-577.

Calderoni A, Mosello R, Quirci A, de Bernardi R, 1990. Recovery of Lake Orta by liming, p. 157-171. In: Proceedings VII Int. Lime Congr., Rome.

Calderoni A, Tartari GA, 2001. Evolution of the water chemistry of Lake Orta after liming. J. Limnol. 60:69-78.

Cattaneo A, Asioli A, Comoli P, Manca M, 1998. Organisms' response in a chronically polluted lake supports hypothesized link between stress and size. Limnol. Oceanogr. 43:1938-1943.

Dean WE, 1974. Determination of carbonate and organic matter in calcareous sediments and sedimentary rocks by loss on ignition; comparison with other methods J. Sed. Res. 44:242-248.

De Schamphelaere KA, Heijerick DG, Janssen CR, 2006. Crossphylum comparison of a chronic biotic ligand model to predict chronic toxicity of copper to a freshwater rotifer, Brachionus calyciflorus (Pallas). Ecotox. Environ. Safe. 63:189-195.

Frey DG, 1964. Remains of animals in Quaternary lake and bog sediments and their interpretation. Arch. Hydrobiol. Beih. Ergebn. Limnol. 2:1-114. 
García-Roger EM, Carmona MJ, Serra M, 1995. Deterioration patterns in diapausing egg banks of Brachionus (Müller, 1786) rotifer species. J. Exp. Mar. Biol. Ecol. 314:149-161.

Gilbert JJ, 1980. Female polymorphism and sexual reproduction in the rotifer Asplanchna: evolution of their relationship and control by dietary tocopherol. Am. Nat. 116:409-431.

Gilbert JJ, 1992. Rotifera, p. 115-136. In: K.G. Adiyodi and R.G. Adiyodi (eds.), Reproductive biology of invertebrates. 5. Sexual differentiation and behaviour. Oxford \& IBH.

Gilbert JJ, 1995 Structure, development and induction of a new diapause stage in rotifers. Freshwater Biol. 34:263-270.

Gilbert JJ, 2007. Timing of diapause in monogonont rotifers: mechanisms and strategies, p. 11-27. In: V.R. Alekseev, B. De Stasio and J.J. Gilbert (eds.), Diapause in aquatic invertebrates theory and human use. Springer.

Gilbert JJ, Wurdak ES, 1978. Species-specific morphology of resting eggs in the rotifer Asplanchna. Trans. Amer. Micros. Soc. 97:330-339.

Guilizzoni P, Lami A, Marchetto A, Appleby PG, Alvisi F, 2001. Fourteen years of palaeolimnological research of a past industrial polluted lake (L. Orta, Northern Italy): an overview. J. Limnol. 60:249-262.

Guilizzoni P, Marchetto A, Lami A, Gerli S, Musazzi S, 2011. Use of sedimentary pigments to infer past phosphorus concentration in lakes. J. Paleolimnol. 45:433-445.

Hall R, Leavitt P, Smol J, Zirnhelt N, 1997. Comparison of diatoms, fossil pigments and historical records as measures of lake eutrophication. Freshwater Biol. 38:401-417.

Jeppesen E, Madsen EA, Jensen JP, Anderson N, 1996. Reconstructing the past density of planktivorous fish and trophic structure from sedimentary zooplankton fossils: a surface sediment calibration data set from shallow lakes Freshwater Biol. 36:115-127.

Kirk KL, 1997. Life-history responses to variable environments: starvation and reproduction in planktonic rotifers. Ecology 78: 434-441.

Koste W, 1978. [Rotatoria. Die Rädertiere Mitteleuropas. Ein Bestimmungswerk, begründet von Max Voigt. Überordnung Monogononta. 2.].[Book in German]. Gebrüder Borntraeger, Berlin Stuttgart: $673 \mathrm{pp}$.

Manca M, Comoli P, 1995. Temporal variations of fossils Cladocera in the sediments of Lake Orta (N. Italy) over the last 400 years. J. Paleolimnol. 14:113-122.

Merkt J, Müller H, 1999. Varve chronology and palynology of the Lateglacial in Northwest Germany from lacustrine sediments of Hämelsee in Lower Saxony. Quat Int. 61:41-59.

Monti R, 1930. [La graduale estinzione della vita nel limnobio del Lago d'Orta].[Article in Italian]. Rend. Ist. Lomb. Sci. Lett. 63:3-22.

Morabito G, Ruggiu D, Panzani P, 2001. Trends of phytoplankton characteristics and their communities in pre- and postliming time in Lake Orta (1984-1998). J. Limnol. 60:39-48.

Mosello R, Bonacina C, Carollo A, Libera V, Tartari GA, 1986. Acidification due to in-lake ammonia oxidation: an attempt to quantify the proton production in a highly polluted subalpine Italian lake (Lake Orta). Mem. Ist. Ital. Idrobiol. 44:47-71.

Odum EP, 1965. Ecology. Holt, Rinehart, and Winston, Inc., New York.

Onbé T, 1978. Sugar flotation method for sorting the resting eggs of marine Cladocerans and Copepods from sea-bottom sediment. Bull. Jpn. Soc. Fish. 44:1411.

Orcutt Jr. JD, Pace ML, 1984. Seasonal dynamics of rotifer and crustacean zooplankton populations in a eutrophic, monomictic lake with a note on rotifer sampling techniques. Hydrobiologia 119: 73-80.

Pace ML, Orcutt JD Jr, 1981. The relative importance of protozoans, rotifers, and crustaceans in a freshwater zooplankton community. Limnol. Oceanogr. 26:822-830.

Parona C, 1880. [Appunti geologici sul bacino del Lago d'Orta].[Article in Italian]. Rend. Ist. Lomb. Sci. Lett. 13:119.

Pavesi P, 1879. Ulteriori studi sulla fauna pelagica dei laghi italiani. Rend. Istit. Lomb. Sci. Lett. 12:688-707.

Pavesi P, 1896. [La distribuzione dei pesci in Lombardia].[Book in Italian]. Società Lombarda per la Pesca e l'Acquicoltura: $40 \mathrm{pp}$.

Pérez-Legaspi IA, Rico-Martínez R. 2001. Acute toxicity tests on three species of the genus Lecane (Rotifera: Monogononta). Hydrobiologia 446/447:375-381.

Pielou EC, 1966. Species-diversity and pattern-diversity in the study of ecological succession. J. Theor. Biol. 10:370383.

Piscia R, Bonacina C, Manca M, 2009. [Il Lago d'Orta: un ambiente in evoluzione, p. 73-80].[Article in Italian]. In: Proc. Accademia dei Lincei "Acque interne in Italia: uomo e natura", Rome.

Piscia R, Colombini M, Ponti B, Bettinetti R, Monticelli D, Rossi V, Manca M, 2015. Lifetime Response of Contemporary Versus Resurrected Daphnia galeata Sars (Crustacea, Cladocera) to $\mathrm{Cu}$ (II) Chronic Exposure. Bull. Env. Cont. Toxicol. 94:46-51.

Piscia R, Guilizzoni P, Fontaneto, Vignati DAL, Appleby PG, Manca M, 2012. Dynamics of rotifer and cladoceran resting stages during copper pollution and recovery in a subalpine lake. Int J. Limnol. 48:151-160.

Rogora M, Kamburska L, Mosello R, Tartari G, 2016. Lake Orta chemical status 25 years after liming: problems solved and emerging critical issues. J. Limnol. 75(s2):93-106.

Ruggiu D, Luglié A, Cattaneo A, Panzani P, 1998. Paleoecological evidence for diatom response to metal pollution in Lake Orta (N. Italy). J Paleolimnol. 20:333-345.

Sanger JE, 1988. Fossil pigments in paleoecology and paleolimnology. Palaeog. Palaeocl. Palaeoecol. 62:343-359.

Shannon CE, Wiener W, 1963. The mathematical theory of communities. University of Illinois Press, Urbana: 117 pp.

Sudzuki M, 1964. New systematical approach to the Japanese planktonic Rotatoria. Hydrobiologia 23:1-124.

ter Braak CJF, Šmilauer P, 2002. CANOCO Reference manual and CanoDraw for Windows user's guide: software for canonical community ordination (version 4.5). Microcomputer Power, Ithaca, USA.

van Dijk GM, van Zanten B, 1995. Seasonal changes in zooplankton abundance in the lower Rhine during. Hydrobiologia 304:29-38.

Vignati DAL, Bettinetti R, Marchetto A, 2016. Long-term persistence of sedimentary copper contamination in Lake Orta: potential environmental risks 20 years after liming. J. Limnol. 75(s2):107-119.

Visconti A, Manca M, de Bernardi R, 2008. Eutrophication-like response to climate warming: an analysis of Lago Maggiore (N. 
Italy) zooplankton in contrasting years. J. Limnol. 67:87-92. Vollenweider RA, 1975. Input-output models. With special reference to the phosphorus loading concept in limnology. Aquat. Sci. 37:53-84

Yan N, Geiling W, 1985. Elevated planktonic rotifer biomass in acidified metal-contaminated lakes near Sudbury, Ontario. Hydrobiologia 120:199-205.

Yoshida T, Kagami M, Gurung TB and Urabe J, 2001. Seasonal succession of zooplankton in the north basin of Lake Biwa. Aquat. Ecol. 35: 9-29. 